\title{
Job demands, job resources, burnout and work engagement of managers at a platinum mine in the North West Province
}

\author{
S. Rothmann* and J.H.M. Joubert \\ WorkWell: Research Unit for People, Policy and Performance, \\ North-West University, P/bag X6001, Potchefstroom, Republic of South Africa \\ Ian.Rothmann@nwu.ac.za
}

Received June 2007

\begin{abstract}
The objective of this study was to investigate the relationships between job demands, job resources, burnout, and engagement of management staff at a platinum mine in the North West Province. A cross-sectional survey design was used. The study population $(N=310)$ consisted of managers at the platinum mine. The Maslach Burnout Inventory General Survey, Utrecht Work Engagement Scale, and the Job Demands-Resources Scale were administered. The results revealed that exhaustion was predicted by workload, job insecurity and a lack of resources, while cynicism was predicted by lack of organisational support and advancement opportunities. Vigour was predicted by organisational support. Dedication was predicted by organisational support and high workload. Engagement was predicted by organisational support.
\end{abstract}

*To whom all correspondence should be addressed.

\section{Introduction}

Globalisation and continued international pressure on organisations to perform better with fewer resources are reflected in the changing psychological contracts between employers and employees. Employees are expected to give more in terms of time, effort, skills and flexibility, whilst job security, career opportunities and lifetime employment are diminishing (Maslach, Schaufeli \& Leiter, 2001). South Africa and its mining industry are not excluded from these pressures and impacts. The need to improve the country's productivity is reflected in its poor ranking $\left(49^{\text {th }}\right.$ of 60 countries) in the World Competitiveness Yearbook (http://www01.imd.ch/wcy). The South African mining industry produces $90 \%$ of the world's platinum-group metals among other minerals. Its contribution to the country's economic activity and productivity is beyond dispute (Gastrow, 2001).

The key differentiator of competitive advantage in the new world economy is the organisation's employees (Minervini, Meyer \& Rourke, 2003). However, employees have to cope with increasing demands from various and diverse roles and organisational stakeholders, often with limited resources (Minervini et al., 2003). Monitoring and improving employee effectiveness in coping with multiple new demands, stimulating their growth and enhancing their wellbeing as well as their organisational performance. In this regard, burnout and engagement are specific research areas (Maslach et al., 2001).

Ivancevich and Matteson (1999) believe that managers are responsible for the effectiveness of individuals, groups and organisations. DuBrin (1990) reports that managers who suffer from burnout, harm organisational effectiveness because they spread it to their subordinates. Burnout can thus be 'contagious' and perpetuates itself through the informal interactions on the job. Rothmann (2002) reports that burnout leads to low morale, job dissatisfaction, staff turnover and absenteeism, and that it can bring about deterioration in the quality of service rendered by staff. From these findings it can be deduced that managers can impact directly or indirectly on employee effectiveness and organisational outcomes such as turnover.

According to Jackson, Rothmann and Van de Vijver (2006), empirical studies have confirmed that burnout is related to health problems and turnover intentions, and that it mediates the relationship between job demands and health problems. Also, engagement mediates the relationship between job resources and turnover intentions.

The objectives of this study were, firstly, to determine the relationships between job demands, job resources, burnout, and engagement at a platinum mine in the North West Province where no research of this kind has been conducted before.

\section{Burnout and engagement}

Although burnout has originally been conceptualised in the context of the helping professions (Rothmann, 2002), it has recently expanded to all types of professions and occupational groups. Schaufeli and Enzmann (1998: 36) define burnout as 'a persistent, negative, work-related state of mind in normal individuals that is primarily characterised by exhaustion, which is accompanied by distress, a sense of reduced effectiveness, decreased motivation, and the development of dysfunctional attitudes and behaviours at work'. Burnout is characterised by emotional exhaustion, 
cynicism and reduced professional efficacy (Barkhuizen, 2005; Jackson \& Rothmann, 2005; Maslach et al., 2001).

Exhaustion and cynicism constitute the core of burnout (Schaufeli, 2003). Exhaustion represents the individual stress component of burnout (Maslach et al., 2001) and refers to feelings of being overextended and depleted of emotional and physical resources, i.e. incapable of work performance because all energy has been drained. In the development of burnout, exhaustion emerges first in response to an overly demanding work environment (Leiter, 1993). Cynicism entails a general indifferent, callous or cynical attitude towards the work. To cope with excessive job demands and feelings of exhaustion, the individual psychologically withdraws from the work (mental distancing) (Maslach et al., 2001). Professional efficacy refers to an individual's negative self-evaluation of competence, achievement and productiveness, as well as feelings of insufficiency (Schaufeli \& Buunk, 1996). Professional efficacy is the weakest burnout dimension in terms of significant relationships with other variables, and is often referred to as the 'least specific' or 'unnecessary' dimension of burnout (Lee \& Ashforth, 1996; Schaufeli, 2003). Several authors argue that professional efficacy reflects a personality characteristic rather than a genuine burnout dimension (Cordes \& Dougherty, 1993; Shirom, 1989).

Seiler and Pearson (1984-5) note that the consequences of dysfunctional stress (burnout) include two forms of withdrawal: the employee may resign (physical withdrawal) or the employee may remain in employment but continue to do the bare minimum (psychological withdrawal). According to Maslach, Jackson and Leiter (1996), burnout is a result of job demands and lack of job resources can lead to negative outcomes such as physical illness, staff turnover and absenteeism. Research has linked burnout to a variety of mental and physical health problems (Lee \& Ashforth, 1990), increased absenteeism (Leiter \& Harvie, 1998), and decreased quality and quantity of work performance (Blix, Cruise, Mitchell \& Blix, 1994). Eventually, individuals may leave the job or profession as a culmination of burnout (Jackson \& Simpson, 2001; Watts et al., 1991).

Empirical studies have revealed that some individuals do not develop burnout, regardless of high job demands and long working hours. On the contrary, they seem to find pleasure in working hard and dealing with job demands (Nelson \& Simmons, 2003; Schaufeli \& Bakker, 2001). This discovery saw the emergence of theoretical and empirical studies on the concept of engagement. Initially, engagement was regarded the direct opposite of burnout (Rothmann, 2002). However, Schaufeli, Salanova, González-Romá and Bakker (2002) have operationalised engagement as a construct in its own right. Research on engagement has adopted a positive psychology perspective that focuses on psychological health and well-being rather than on psychological ill health - as is the case with burnout (Seligman \& Csikszentmihalyi, 2000).

Schaufeli and Bakker (2004) define engagement as a positive, fulfilling work-related state of mind, characterised by vigour, dedication and absorption. It is not focused on a specific object, event, individual or behaviour (Schaufeli et al., 2002). Vigour refers to high levels of energy and resilience, willingness to invest effort in one's work, and perseverance in the face of difficulties. Dedication refers to strong involvement in one's work, accompanied by feelings of enthusiasm and significance, and a sense of pride and inspiration (Maslach et al., 2001). Absorption refers to a satisfactory state of complete emersion in one's work, which is characterised by focused attention, time distortion, loss of self-consciousness, effortless concentration, absolute control, and intrinsic enjoyment (Csikszentmihalyi,1990). However, absorption seems to be a problematic dimension from a validity perspective.

According to Schaufeli and Bakker (2004), burnout and engagement are indicators of employees' wellness. Therefore, burnout and work engagement can be integrated as one model (Rothmann, 2002). According to Maslach et al. (2001), the study of work-related experiences should include the entire continuum of work-related experiences, ranging from negative (burnout) to positive (work engagement). However, burnout and engagement are best measured with different instruments (Schaufeli et al., 2002). The Maslach Burnout Inventory - General Survey (MBIGS) measures burnout across occupational settings, whilst the Utrecht Work Engagement Scale (UWES) measures engagement more effectively (Schaufeli et al., 2002).

\section{Job demands and resources}

Several theories and models have been developed to explain the effects of job demands (e.g. work overload) and lack of resources (e.g. job control) on burnout. These include the Conservation of Resources (COR) theory (Hobfoll \& Freedy, 1993; Lee \& Ashforth, 1996), the Job DemandsResources (JD-R) model (Demerouti et al., 2001) and the Comprehensive Burnout and Engagement (COBE) model, an extension of the JD-R model with engagement, health impairment and organisational withdrawal as additional components (Schaufeli \& Bakker, 2004). The theory underlying these models proposes that burnout develops in response to excessive job demands and diminished job resources.

The COBE model assumes two job-related psychological processes, namely an energetic and a motivational process (Jackson, Rothmann \& Van de Vijver, 2006). The energetic process links job demands with health problems via burnout. The motivational process links job resources with organisational outcomes via work engagement. The model has been confirmed in the Netherlands by Schaufeli and Bakker (2004) in an empirical study, with job demands being associated with exhaustion, and job resources with work engagement. Burnout is mainly predicted by job demands and lack of resources, it is related to health problems and turnover intentions, and mediates the relationship between job demands and health problems. Engagement is exclusively predicted by availability of job resources, relates only to turnover intentions, and mediates the relationship between job resources and turnover intentions.

The COR theory (Hobfoll \& Freedy, 1993) suggests that burnout is likely to develop when valued resources are lost 
or threatened, or are inadequate to meet the demands. Major demands include role ambiguity, work pressure and workload. Major resources include control, participation in decision-making and job autonomy (Lee \& Ashforth, 1996). According to Leiter (1993), demands and resources are related. A work environment which is overly demanding usually also offers insufficient resources.

Taris, Schreurs and Schaufeli (1999) report that a strong correlation exists between burnout and job stress (situational or organisational factors). Schaufeli and Enzmann (1998) categorise organisational stressors as job demands and lack of job resources. Job demands refer to the things that have to be done or activities to be performed, and include the physical, social or organisational aspects of the job that require sustained physical and mental effort (Demerouti, Bakker, Nachreiner \& Schaufeli, 2001). Job demands include situational factors such as role ambiguity, role conflict, stressful events, heavy workload and work pressure, pressure to make critical and immediate decisions, being assigned more responsibility, and having to meet deadlines (Rothmann, 2002; Schaufeli \& Enzmann, 1998).

Many burnout researchers have studied quantitative job demands (e.g. too much work for the available time). The findings generally indicate that burnout is a response to overload. Heavy workload and time pressure are strongly and consistently related to burnout, particularly the exhaustion dimension (Maslach et al., 2001). Studies of qualitative job demands have focused primarily on role conflict and role ambiguity, both of which consistently show a moderate to high correlation with burnout. Role conflict occurs when conflicting demands at the job have to be met, whereas role ambiguity occurs when there is a lack of adequate information to do the job well (Maslach et al., 2001).

Job resources refer to all aspects (physical, psychological, social and/or organisational) that reduce job demands, facilitate achievement of work goals, and/or stimulate individual growth (Demerouti et al., 2001b; Rothmann, 2002). Job resources include social support (supervisory and collegial), job enhancement opportunities in the form of increased control and autonomy, participation in decisionmaking, reinforcement contingencies (Burke \& Richardsen, 1993), as well as recognition, opportunities for advancement and rewards (Rothmann, 2002).

Burnout researchers have also investigated the absence of job resources. Consistent and strong evidence exists of a correlation between lack of social support and burnout, with lack of supervisory support being more important than support from co-workers (Maher, 1983; Maslach et al., 2001). Correlations have also been confirmed between lack of feedback and all three dimensions of burnout, and between lack of autonomy and burnout. People who enjoy little participation in decision-making seem to experience higher levels of burnout (Maslach et al., 2001).

Based on the above discussion, the following hypotheses are formulated:
Hypothesis 1: Burnout is predicted by job demands (i.e. work overload) and a lack of job resources.

Hypothesis 2: Work engagement (vigour and dedication) is predicted by job resources.

\section{Method}

\section{Research design}

A cross-sectional survey design was used.

\section{Participants}

Of the study population $(N=310)$, a sample of 202 management-level employees across the different operational units of a platinum mine in the North West Province was taken. The characteristics of the participants are shown in Table 1.

The sample consisted mainly of Afrikaans-speaking (61,90\%) and English-speaking participants (25,70\%). They were mainly within the age group 41 to $50(45 \%)$, white $(84,70 \%)$ and men $(88,60 \%)$. Most were employed at the first level of management, namely D-Level Paterson Grading $(67,40 \%)$ and $26,20 \%$ have attained a technikon diploma.

\section{Measuring instruments}

The follow instruments were used in this study:

The Maslach Burnout Inventory - General Survey (MBIGS) (Maslach et al., 1996) was used to measure burnout. In line with our theoretical model, only two subscales of the MBI-GS, namely Exhaustion (five items, e.g. 'I feel used up at the end of the workday') and Cynicism (five items, e.g. 'I have become less enthusiastic about my work') were used for the purposes of this study. The third scale of the MBIGS was not used for the purposes of this study. Schaufeli, Van Dierendonck and Van Gorp (1996) reported Cronbach coefficient alphas varying from 0,87 to 0,89 for Exhaustion, and 0,73 to 0,84 for Cynicism. Test-retest reliabilities after one year were 0,65 (Exhaustion), and 0,60 (Cynicism). The items are scored on a seven-point frequency rating scale ranging from 0 (never) to 6 (always). In South African studies, Cronbach alpha coefficients ranged from 0,86 to 0,88 for Exhaustion, and from 0,79 to 0,80 for Cynicism (Coetzer \& Rothmann, 2004; Storm \& Rothmann, 2003a).

The Utrecht Work Engagement Scale (UWES) (Schaufeli et al., 2002) was applied to measure participants' levels of engagement. In line with our theoretical model, only two subscales of the UWES were used for the purposes of this study, namely Vigour (five items, e.g. 'I am bursting with energy in my work'), and Dedication (five items, e.g. 'I find my work full of meaning and purpose'). Items are scored on a seven-point scale ranging from 0 (never) to 6 (always). The alpha coefficients for the three subscales varied between 0,68 and 0,91 (Schaufeli et al., 2002). Alpha coefficients varied between 0,78 and 0,89 for the two subscales. Storm and Rothmann (2003b) obtained alpha coefficients of 0,78 for Vigour, and 0,89 for Dedication. 
Table 1: Characteristics of the participants $(N=202)$

\begin{tabular}{|c|c|c|}
\hline Variable & Category & Percentage \\
\hline \multirow[t]{5}{*}{ Age (years) } & $25-30$ & 7,9 \\
\hline & $31-40$ & 32,2 \\
\hline & $41-50$ & 45,0 \\
\hline & $>51$ & 14,4 \\
\hline & Missing values & 0,5 \\
\hline \multirow[t]{4}{*}{ Language } & Afrikaans & 61,9 \\
\hline & English & 25,7 \\
\hline & Setswana & 4,0 \\
\hline & Other African languages & 8,5 \\
\hline \multirow[t]{3}{*}{ Gender } & Male & 88,6 \\
\hline & Female & 10,4 \\
\hline & Missing values & 1,0 \\
\hline \multirow[t]{4}{*}{ Race } & White & 84,7 \\
\hline & Black & 11,9 \\
\hline & Other & 3,0 \\
\hline & Missing values & 0,5 \\
\hline \multirow[t]{6}{*}{ Education } & Grade 12 or below & 22,3 \\
\hline & $\begin{array}{l}\text { Technical College } \\
\text { Certificate }\end{array}$ & 11,4 \\
\hline & Technikon Diploma & 26,2 \\
\hline & Degree & 14,4 \\
\hline & Postgraduate qualification & 22,8 \\
\hline & Missing values & 3,0 \\
\hline \multirow{4}{*}{$\begin{array}{l}\text { Management } \\
\text { Level/Job } \\
\text { Grading }\end{array}$} & D level & 67,4 \\
\hline & E level & 24,3 \\
\hline & $\begin{array}{l}\text { F level (include executive } \\
\text { team) }\end{array}$ & 6,5 \\
\hline & Missing values & 2,0 \\
\hline \multirow{4}{*}{$\begin{array}{l}\text { Years in current } \\
\text { job }\end{array}$} & $<1$ & 20,3 \\
\hline & $1-5$ & 27,3 \\
\hline & $5-10$ & 26,7 \\
\hline & $>10$ & 25,7 \\
\hline \multirow[t]{4}{*}{ Years in service } & $<1$ & 5,0 \\
\hline & $1-5$ & 25,0 \\
\hline & $5-10$ & 30,7 \\
\hline & $>10$ & 38,1 \\
\hline
\end{tabular}

The Job Demands-Resources Scale (JDRS) was developed for the organisation through focus group interviews. The contextualised questionnaire consists of 67 items and measures job demands and job resources for employees. Questions are rated on a four-point scale ranging from 1 (always) to 4 (never). The dimensions of the JDRS include pace, amount and variety of work, physical, mental and emotional workload, opportunities to learn, work independence, relationships with colleagues and immediate supervisor, ambiguities of work, information, communications, participation, contact possibilities, uncertainty about the future, remuneration and career possibilities.

\section{Statistical analysis}

The statistical analysis was carried out with the SPSS program (SPSS Inc., 2003) and the AMOS program (Arbuckle, 1999). Cronbach alpha coefficients and factor analysis were used to assess the reliability and validity of the measuring instruments (Clark \& Watson, 1995). Descriptive statistics (e.g. means and standard deviations) were used to analyse the data. Pearson correlation coefficients were computed to determine the relationships between variables. A cut-off point of $p \leq 0,05$ was set for the statistical significance of the results. Effect sizes (Cohen, 1988) were used to decide on the practical significance of the findings. A cut-off point of 0,30 (medium effect, Cohen, 1988) was set for the practical significance of correlation coefficients.

Exploratory factor analyses were carried out to investigate the construct validity of the following a two-step procedure. First, a simple principal components analysis was conducted on the constructs that form part of the measurement model, including burnout and work engagement. The eigenvalues and scree plots were studied to determine the number of factors. Second, a principal axis factor analysis with a direct oblimin rotation was conducted if factors were related, and a principal component analysis with a varimax rotation was used if the obtained factors were not related (Tabachnick \& Fidell, 2001).

Structural equation modelling was used to assess the factorial validity of the measuring instruments of burnout, and work engagement. Among the fit indices produced by the AMOS program is the Chi-square statistic $\left(\chi^{2}\right)$, which is the test of absolute fit of the model. However, the $\chi^{2}$ value is sensitive to sample size. Therefore additional goodness-offit indices, such as the Goodness-of-Fit Index (GFI), the Adjusted Goodness-of-Fit Index (AGFI), the Normed Fit Index (NFI), the Comparative Fit Index (CFI), the TuckerLewis Index (TLI) and the Root Means Square Error of Approximation (RMSEA), were used in this study.

Standard multiple regression analysis was used to determine which combination of job demands and job resources best predict burnout and work engagement (Tabachnick \& Fidell, 2001).

\section{Results}

Structural equation modelling (SEM) methods, as implemented by AMOS (Arbuckle, 1999), were used to test the factorial models of the MBI-GS and the UWES. Data analysis was conducted in two consecutive steps. Firstly, 
quick overviews of the model fits were done by inspecting the overall $\chi^{2}$ values, together with the degrees of freedom and probability values. Several goodness-of-fit statistics (GFI, AGFI, NFI, TLI, CFI and RMSEA) were used to globally assess the model fits. Secondly, given findings of poorly fitting initially hypothesised models, the focus shifted from model testing to model development (exploratory factor analysis). Exploratory factor analyses were done for the JDRS Subscales.

\section{Hypothesised model: MBI-GS}

Two competing models of burnout were tested, namely a one-factor model and a two-factor model were tested. Table 2 presents fit statistics for the test of the original and other models.

Table 2 indicates that the statistically significant $\chi^{2}$ value of $179,04(d f=35 ; p=0,00)$ revealed a relatively poor overall fit of the hypothesised one-factor MBI model. Seen from a practical perspective, Model 1 was not good either. The GFI, NFI, TLI and CFI values lower than 0,95, and the RMSEA values higher than 0,05 are indicative of failure to confirm the hypothesised models. It is thus apparent that some modification in specification is needed in order to determine a model that fits the sample data better.

The fit of the two-factor MBI model was substantially better $\left(\chi^{2}=320,63 ; d f=34 ; p=0,00\right)$. However, the standardised regression coefficient of item 13 (which is supposed to measure Cynicism) was low. It was therefore decided to remove this item. The fit of the two-factors of model was acceptable (with all the fit indices higher than 0,90).

Similar procedures were followed to determine the fit statistics for the UWES.

Both one-factor and two-factor models were tested. Table 3 shows that a two-factor model, labelled here as Model 2, better fits the data set with a lower $\chi^{2}$ value of $90,99(d f=$ $43 ; p=0,00)$. The fit indices were all higher than 0,90 , while the $\chi^{2} / d f$ is lower than 5. The RMSEA value of 0,08 was also acceptable compared to the guideline (it should not be higher than 0,08 ). In order to determine a model that better represents the sample data, modification indices (MI) were examined to identify possible areas of misfit. Item 15 was retained in spite of a relatively low standardised regression weight of 0,38 . The subsequent analysis is therefore based on a two-factor model of the UWES.

A simple component analysis that was conducted on the 67 items of the JDRS resulted in five factors, which explained $42,16 \%$ of the variance. Next, a principal axis factor analysis with a varimax rotation was conducted on the items. The results of the factor analysis on the JDRS are shown in Table 4. The loading of variables on factors is shown. Labels for each factor are suggested in the footnote.

Table 2: The goodness-of-fit statistics for the hypothesised MBI-GS model

\begin{tabular}{l|c|c|c|c|c|c|c}
\hline Model & $\chi^{2}$ & $\chi^{2} / d f$ & GFI & NFI & IFI & CFI & RMSEA \\
\hline Model 1- One factor & 179,04 & 5,12 & 0,82 & 0,78 & 0,82 & 0,81 & 0,14 \\
\hline $\begin{array}{l}\text { Model 2- Two-factor } \\
\text { model }\end{array}$ & 64,82 & 1,91 & 0,94 & 0,92 & 0,96 & 0,96 & 0,07 \\
\hline $\begin{array}{l}\text { Model 2- Two-factor } \\
\text { model and item 13 } \\
\text { removed }\end{array}$ & 59,57 & 2,29 & 0,94 & 0,91 & 0,95 & 0,95 & 0,08 \\
\hline
\end{tabular}

Table 3: The goodness-of-fit statistics for the hypothesised UWES model

\begin{tabular}{l|c|c|c|c|c|c|c}
\hline Model & $\chi^{2}$ & $\chi^{2} / d f$ & GFI & NFI & IFI & CFI & RMSEA \\
\hline Model 1- One-factor & 104,71 & 2,38 & 0,91 & 0,91 & 0,95 & 0,94 & 0,08 \\
\hline Model 2 - Two-factor & 90,99 & 2,12 & 0,92 & 0,92 & 0,96 & 0,96 & 0,08 \\
\hline
\end{tabular}


Table 4: Factor loadings for principal factor extraction and varimax rotation on JDRS items

\begin{tabular}{|c|c|c|c|c|c|}
\hline Item & $F_{1}$ & $\boldsymbol{F}_{2}$ & $\boldsymbol{F}_{3}$ & $\boldsymbol{F}_{4}$ & $\boldsymbol{F}_{5}$ \\
\hline I feel that my manager appreciates my work & 0,79 & 0,00 & 0,00 & 0,00 & 0,00 \\
\hline I can discuss work problems with my manager & 0,77 & 0,00 & 0,00 & 0,00 & 0,00 \\
\hline My manager informs me about how well I am doing my work & 0,75 & 0,00 & 0,00 & 0,00 & 0,00 \\
\hline I get on well with my manager & 0,74 & 0,00 & 0,00 & 0,00 & 0,00 \\
\hline The department's decision-making process is clear to me & 0,73 & 0,00 & 0,00 & 0,00 & 0,00 \\
\hline I can count on my manager when I come across difficulties in my work & 0,73 & 0,00 & 0,00 & 0,00 & 0,00 \\
\hline I know exactly what my manager thinks of my performance & 0,72 & 0,00 & 0,00 & 0,00 & 0,00 \\
\hline I am kept adequately up to date about important issues in the department & 0,71 & 0,00 & 0,00 & 0,00 & 0,00 \\
\hline I can participate in decisions about the nature of my work & 0,66 & 0,00 & 0,00 & 0,00 & 0,00 \\
\hline I receive information on the results of my work & 0,64 & 0,00 & 0,00 & 0,00 & 0,00 \\
\hline I receive information on the purpose of my work & 0,64 & 0,00 & 0,00 & 0,00 & 0,00 \\
\hline I know exactly what I am responsible for & 0,58 & 0,00 & 0,00 & 0,00 & 0,00 \\
\hline I have a direct influence on the department's decisions & 0,55 & 0,00 & 0,00 & 0,00 & 0,00 \\
\hline I receive up-to-date information about the changes and transformation in the company & 0,54 & 0,00 & 0,00 & 0,00 & 0,00 \\
\hline It is clear to me who I should address within the department about specific problems & 0,54 & 0,00 & 0,00 & 0,00 & 0,00 \\
\hline I know exactly what is expected of me in my work & 0,54 & 0,00 & 0,00 & 0,00 & 0,00 \\
\hline I am allowed to influence the planning of my work activities & 0,52 & 0,00 & 0,00 & 0,00 & 0,00 \\
\hline I can participate in the decision about when a job must be completed & 0,50 & 0,00 & 0,00 & 0,00 & 0,00 \\
\hline My job offers me the opportunity of independent thought and action & 0,47 & 0,00 & 0,00 & 0,00 & 0,00 \\
\hline I have freedom in carrying out my work activities & 0,47 & 0,00 & 0,00 & 0,00 & 0,00 \\
\hline I clearly understand my role in the change process of the company & 0,45 & 0,00 & 0,00 & 0,00 & 0,00 \\
\hline I feel that I can achieve something in my work & 0,43 & 0,00 & 0,00 & 0,00 & 0,00 \\
\hline I have contact with colleagues as part of my work & 0,36 & 0,00 & 0,00 & 0,00 & 0,00 \\
\hline I have to give attention to many things at the same time & 0,00 & 0,69 & 0,00 & 0,00 & 0,00 \\
\hline I work under time pressure & 0,00 & 0,66 & 0,00 & 0,00 & 0,00 \\
\hline I have too much work to do & 0,00 & 0,60 & 0,00 & 0,00 & 0,00 \\
\hline I have to remember many things in my work & 0,00 & 0,55 & 0,00 & 0,00 & 0,00 \\
\hline I receive an overload of information in my work & 0,00 & 0,54 & 0,00 & 0,00 & 0,00 \\
\hline Different people expect different things of me in my work & 0,00 & 0,53 & 0,00 & 0,00 & 0,00 \\
\hline In my job I am confronted with things that affect me personally & 0,00 & 0,50 & 0,00 & 0,00 & 0,00 \\
\hline My work requires continuous attention from me & 0,00 & 0,48 & 0,00 & 0,00 & 0,00 \\
\hline In my work I have to deal with power struggles between people from different groups & 0,00 & 0,47 & 0,00 & 0,00 & 0,00 \\
\hline My work puts me in emotionally upsetting situations & 0,00 & 0,47 & 0,00 & 0,00 & 0,00 \\
\hline I have contact with difficult people in my work & 0,00 & 0,44 & 0,00 & 0,00 & 0,00 \\
\hline I have variety in my work & 0,00 & 0,41 & 0,00 & 0,00 & 0,00 \\
\hline My work uses my skills and capacities to their full potential & 0,00 & 0,39 & 0,00 & 0,00 & 0,00 \\
\hline My responsibilities have increased beyond my area of technical expertise & 0,00 & 0,38 & 0,00 & 0,00 & 0,00 \\
\hline I have to solve my subordinates' personal problems & 0,00 & 0,00 & 0,00 & 0,00 & 0,00 \\
\hline I am able to effectively use technology in my workplace & 0,00 & 0,00 & 0,68 & 0,00 & 0,00 \\
\hline I have people at the right time to get the work done & 0,00 & 0,00 & 0,66 & 0,00 & 0,00 \\
\hline My subordinates are skilled to get the work done & 0,00 & 0,00 & 0,60 & 0,00 & 0,00 \\
\hline If necessary I can ask my colleagues for help & 0,00 & 0,00 & 0,57 & 0,00 & 0,00 \\
\hline
\end{tabular}




\begin{tabular}{|c|c|c|c|c|c|}
\hline I have the necessary equipment to get my work done & 0,00 & 0,00 & 0,52 & 0,00 & 0,00 \\
\hline I can count on my colleagues for help when I come across difficulties in my work & 0,00 & 0,00 & 0,51 & 0,00 & 0,00 \\
\hline My work objectives can be achieved within the approved budget & 0,00 & 0,00 & 0,49 & 0,00 & 0,00 \\
\hline I get on well with my colleagues & 0,00 & 0,00 & 0,46 & 0,00 & 0,00 \\
\hline I have contact with colleagues during working hours & 0,00 & 0,00 & 0,39 & 0,00 & 0,00 \\
\hline I am able to keep up with the pace at which new technology is introduced in my work & 0,00 & 0,00 & 0,35 & 0,00 & 0,00 \\
\hline My job offers me the possibility to progress financially & 0,00 & 0,00 & 0,00 & 0,68 & 0,00 \\
\hline The company pays good salaries & 0,00 & 0,00 & 0,00 & 0,66 & 0,00 \\
\hline I can live comfortably on my pay & 0,00 & 0,00 & 0,00 & 0,66 & 0,00 \\
\hline I think I am paid enough for the work I do & 0,00 & 0,00 & 0,00 & 0,64 & 0,00 \\
\hline My budget can be changed to accommodate unforeseen circumstances & 0,00 & 0,00 & 0,00 & 0,51 & 0,00 \\
\hline I have opportunities to be promoted & 0,00 & 0,00 & 0,00 & 0,50 & 0,00 \\
\hline My job offers me opportunities for personal growth and development & 0,00 & 0,00 & 0,00 & 0,48 & 0,00 \\
\hline My company gives me opportunities to attend training courses & 0,00 & 0,00 & 0,00 & 0,42 & 0,00 \\
\hline I can influence the budget allocation for my work & 0,00 & 0,00 & 0,00 & 0,41 & 0,00 \\
\hline I need to be more secure that I will still be on the same job level in 6 months' time & 0,00 & 0,00 & 0,00 & 0,00 & 0,83 \\
\hline I need to be more secure that I will keep my current job in the next year & 0,00 & 0,00 & 0,00 & 0,00 & 0,83 \\
\hline I need to be more secure that I will still be working for the company in 6 months' time & 0,00 & 0,00 & 0,00 & 0,00 & 0,83 \\
\hline I need to be more secure about what my future role or job in the company will be & 0,00 & 0,00 & 0,00 & 0,00 & 0,67 \\
\hline
\end{tabular}

Factor labels: $\mathrm{F}_{1}$ : Organisational Support, $\mathrm{F}_{2}$ : Workload, $\mathrm{F}_{3}$ : Resources, $\mathrm{F}_{4}$ : Advancement Opportunities, $\mathrm{F}_{5}$ : Job Security.

The five factors that were extracted accounted for $42,16 \%$ of the total variance in the data. With a cut-off of 0,35 for inclusion of a variable in interpretation of a factor, seven of the 67 items did not load on the five factors. Items 42, 43, 44 and 61 did not load strongly $(<0,35)$ on any of the factors and were removed from the questionnaire. Items 4 , 21 and 34 could not be grouped into a meaningful factor and were also removed from the questionnaire.

The first factor was labelled Organisational Support. Items loading on this factor relate to managerial support, communication, role clarity, and the extent of work autonomy. The second factor was labelled Workload and encompasses physical, cognitive and emotional load. Items loading on this factor relate to time pressure, attentiveness to many things at the same time, too much work to do, and dealing with power struggles. The third factor was labelled Resources and involves a variety of resources including collegial support, physical resources such as staff and equipment, as well as financial resources. The fourth factor was labelled Advancement Opportunities. Items loading on this factor relate to growth and development, promotion and financial progress. The fifth factor was labelled Job Security. This factor reflects respondents' indications about being secure in keeping their current jobs in the next year, and about keeping their current job levels in the next year.

Table 5 reports the descriptive statistics, Cronbach alpha coefficients and product-moment correlation coefficients of the measuring instruments, namely the MBI-GS, UWES, and JDRS.

Compared to the guideline of 0,70 provided by Nunnally and Bernstein (1994) for Cronbach coefficient alpha levels, Table 5 shows acceptable Cronbach alpha coefficients varying from 0,79 to 0,94 for all the scales. In conclusion, it can be said that all the instruments showed sufficient reliability to be used for the subsequent analysis. Exhaustion is positively related to Workload, and negatively related to Organisational Support (both medium effects). Cynicism is practically significantly negatively related to Organisational Support and Advancement (both medium effects). Vigour (medium effect) and Dedication (large effect) are practically significantly related to Organisational Support.

Multiple regression analyses were carried out with exhaustion and cynicism (as measured by the MBI-GS), vigour and dedication (as measured by the UWES) as dependent variables, and job demands and resources (as measured by the JDRS) as independent variables (see Table 6 ). The multiple regression analyses were carried out by entering the independent variables in blocks in two steps. In the case of exhaustion, overload and job insecurity (as demands) were entered in the first step, while organisational support, resources and advancement (as job resources) were entered in the second step. 
Table 5: Descriptive statistics, alpha coefficients and product-moment correlation coefficients of the scales

\begin{tabular}{|c|c|c|c|c|c|c|c|c|c|c|c|}
\hline Item & Mean & $S D$ & $\alpha$ & 1 & 2 & 3 & 4 & 5 & 6 & 7 & 8 \\
\hline 1. Exhaustion & 13,44 & 5,84 & 0,84 & - & - & - & - & - & - & - & - \\
\hline 2. Cynicism & 7,80 & 5,25 & 0,83 & $0,54^{*++}$ & - & - & - & - & - & - & - \\
\hline 3. Vigour & 21,13 & 4,77 & 0,78 & $-0,48^{*+}$ & $-0,52^{*++}$ & - & - & - & - & - & - \\
\hline 4. Dedication & 23,10 & 5,12 & 0,88 & $-0,37^{*+}$ & $-0,59^{*++}$ & $0,76^{*++}$ & - & - & - & - & - \\
\hline $\begin{array}{ll}\text { 5. Organisational } \\
\text { Support }\end{array}$ & 46,33 & 12,41 & 0,94 & $-0,30^{*+}$ & $-0,42^{*+}$ & $0,43^{*+}$ & $0,55^{*++}$ & - & - & - & - \\
\hline 6. Workload & 27,77 & 5,38 & 0,80 & $0,39^{*+}$ & 0,05 & 0,11 & $0,23^{*}$ & 0,08 & - & - & - \\
\hline 7. Resources & 19,96 & 4,49 & 0,79 & $-0,28^{*}$ & $-0,20^{*}$ & $0,25^{*}$ & $0,29^{*}$ & $0,54^{*++}$ & $-0,03$ & - & - \\
\hline 8. Advancement & 22,06 & 4,80 & 0,79 & $-0,29^{*}$ & $-0,36^{*+}$ & $0,29^{*}$ & $0,30^{*+}$ & $-0,49^{*+}$ & 0,02 & $-0,29^{*}$ & - \\
\hline 9. 10. Job Security & 9,25 & 3,57 & 0,90 & $-0,25^{*}$ & $-0,22^{*}$ & $0,14^{*}$ & 0,09 & $-0,11$ & 0,11 & 0,08 & $-0,11$ \\
\hline
\end{tabular}

* Statistically significant: $p \leq 0,01$

+ Practically significant: $r \geq 0,30$ (medium effect)

++ Practically significant: $r \geq 0,50$ (large effect)

Table 6: Multiple regression analyses with exhaustion and cynicism as dependent variables

\begin{tabular}{|c|c|c|c|c|c|c|c|c|c|}
\hline \multirow[t]{2}{*}{ Model } & \multicolumn{2}{|c|}{$\begin{array}{l}\text { Non-standardised } \\
\text { Coefficients }\end{array}$} & \multirow{2}{*}{$\begin{array}{c}\text { Standardised } \\
\text { Coefficients }\end{array}$} & \multirow[t]{2}{*}{$t$} & \multirow[t]{2}{*}{$p$} & \multirow[t]{2}{*}{$F$} & \multirow[t]{2}{*}{$R$} & \multirow[t]{2}{*}{$R^{2}$} & \multirow[t]{2}{*}{$\Delta R^{2}$} \\
\hline & B & $\mathrm{SE}$ & & & & & & & \\
\hline \multicolumn{4}{|l|}{ Exhaustion - Step 1} & & & $24,41 *$ & 0,44 & 0,20 & $0,20 *$ \\
\hline (Constant) & 27,71 & 2,09 & & 13,26 & 0,00 & & & & \\
\hline Workload & $-0,40$ & 0,07 & 0,37 & $-5 ., 46$ & $0,00 *$ & & & & \\
\hline Job Security & $-0,35$ & 0,11 & $-0,21$ & $-3,32$ & $0,00^{*}$ & & & & \\
\hline \multicolumn{4}{|l|}{ Exhaustion - Step 2} & & & $19,43^{*}$ & 0,58 & 0,33 & $0,13^{*}$ \\
\hline (Constant) & 16,30 & 2,73 & & 5,97 & 0,00 & & & & \\
\hline Workload & 0,41 & 0,06 & 0,38 & 6,45 & $0,00 *$ & & & & \\
\hline Job Security & 0,32 & 0,10 & $-0,20$ & 3,24 & $0,00^{*}$ & & & & \\
\hline Organisational Support & $-0,07$ & 0,04 & $-0,14$ & $-1,81$ & 0,07 & & & & \\
\hline Resources & $-0,24$ & 0,09 & $-0,19$ & $-2,64$ & $0,01^{*}$ & & & & \\
\hline Advancement Opportunities & $-0,17$ & 0,08 & $-0,14$ & $-2,06$ & 0,04 & & & & \\
\hline \multicolumn{4}{|l|}{ Cynicism - Step 1} & & & $17,68 *$ & 0,46 & 0,21 & $0,21 *$ \\
\hline (Constant) & $-2,86$ & 1,90 & & $-1,51$ & 0,13 & & & & \\
\hline Organisational Support & 0,15 & 0,04 & $-0,35$ & $4 ., 25$ & 0,00 & & & & \\
\hline Resources & $-0,05$ & 0,09 & $-0,05$ & $-0,62$ & $0, .54$ & & & & \\
\hline Advancement Opportunities & 0,22 & 0,08 & $-0,20$ & 2,81 & 0,01 & & & & \\
\hline \multicolumn{4}{|l|}{ Cynicism - Step 2} & & & $12,35^{*}$ & 0,49 & 0,24 & 0,03 \\
\hline (Constant) & 0,87 & 2.62 & & 0,33 & 0,74 & & & & \\
\hline Organisational Support & 0,14 & 0,04 & $-0,33$ & 3,97 & $0,00 *$ & & & & \\
\hline Resources & $-0,02$ & 0,09 & $-0,02$ & $-0,22$ & 0,83 & & & & \\
\hline Advancement Opportunities & 0,21 & 0,08 & $-0,19$ & 2,62 & $0,01^{*}$ & & & & \\
\hline Workload & $-0,05$ & 0,06 & 0,06 & $-0,87$ & 0,39 & & & & \\
\hline Job Security & $-0,23$ & 0,10 & $-0,16$ & $-2,43$ & 0,02 & & & & \\
\hline
\end{tabular}

$* p<0,01$ 
Table 6 shows that $20 \%$ of the variance in Exhaustion (as measured by the MBI-GS) is predicted by Workload $(\beta=$ $0,37 ; p<0,01)$ and low Job Security $(\beta=-0,21 ; p<0,01)$, as measured by the JDRS. Furthermore, $33 \%$ of the variance in Exhaustion (as measured by the MBI-GS) is predicted by the factors of the JDRS. However, only the regression coefficients of Workload $(\beta=0,38 ; p<0,01)$, low Job Security $(\beta=-0,20 ; p<0,01)$, and a lack of Resources $(\beta=$ $0,19 ; p<0,01)$ were statistically significant. Adding the three job resources to the multiple regression significantly increased the $R^{2}$ from 0,19 to 0,31 .

Table 6 shows that $21 \%$ of the variance in Cynicism (as measured by the MBI-GS) is predicted by low Organisational Support $(\beta=-0,35 ; p<0,01)$ and low Advancement Opportunities $(\beta=-0,20 ; p<0,01)$, as measured by the JDRS. Furthermore, $24 \%$ of the variance in Cynicism (as measured by the MBI-GS) is predicted by the factors of the JDRS. However, only the regression coefficients of Organisational Support $(\beta=0,33 ; p<0,01)$, and a low Advancement Opportunities $(\beta=-0,19 ; p<0,01)$ were statistically significant. Adding Workload and Job Security to the multiple regression did not have any statistically significant effect on the $R^{2}$ in Step 2 .

Table 7 shows that $20 \%$ of the variance in Vigour (as measured by the UWES) is predicted by job resources (as measured by the JDRS). However, only the regression coefficient of Workload $(\beta=0,36 ; p<0,01)$ was statistically significant. Furthermore, $21 \%$ of the variance in Vigour (as measured by the UWES) is predicted by the factors of the JDRS. However, only the regression coefficient of Organisational Support $(\beta=0,33 ; p<0,01)$ was statistically significant. Adding Workload and Job Security in Step 2, did not have statistically significant effects on the Vigour of participants.

Table 7: Multiple regression analyses with vigour and dedication as dependent variables

\begin{tabular}{|c|c|c|c|c|c|c|c|c|c|}
\hline \multirow[t]{2}{*}{ Model } & \multicolumn{2}{|c|}{$\begin{array}{l}\text { Non-standardised } \\
\text { Coefficients }\end{array}$} & \multirow{2}{*}{$\frac{\begin{array}{c}\text { Standardised } \\
\text { Coefficients }\end{array}}{\text { Beta }}$} & \multirow[t]{2}{*}{$t$} & \multirow[t]{2}{*}{$p$} & \multirow[t]{2}{*}{$F$} & \multirow[t]{2}{*}{$R$} & \multirow[t]{2}{*}{$R^{2}$} & \multirow[t]{2}{*}{$\Delta R^{2}$} \\
\hline & $\mathrm{B}$ & $\mathrm{SE}$ & & & & & & & \\
\hline \multicolumn{4}{|l|}{ Vigour - Step 1} & & & $15,54^{*}$ & 0,44 & 0,19 & $0,19 *$ \\
\hline (Constant) & 30,34 & 1,74 & & 17,41 & 0,00 & & & & \\
\hline Organisational support & $-0,14$ & 0,03 & 0,36 & $-4,38$ & $0,00 *$ & & & & \\
\hline Resources & $-0,02$ & 0,08 & 0,02 & $-0,28$ & 0,78 & & & & \\
\hline Advancement opportunities & $-0,10$ & 0,07 & 0,10 & $-1,43$ & 0,16 & & & & \\
\hline \multicolumn{4}{|l|}{ Vigour - Step 2} & & & $10,34^{*}$ & 0,46 & 0,21 & 0,02 \\
\hline (Constant) & 31,38 & 2,43 & & 12,94 & 0,00 & & & & \\
\hline Organisational support & $-0,13$ & 0,03 & 0,33 & $-3,97$ & $0,00 *$ & & & & \\
\hline Resources & $-0,05$ & 0,08 & 0,04 & $-0,57$ & 0,57 & & & & \\
\hline Advancement opportunities & $-0,10$ & 0,07 & 0,10 & $-1,42$ & 0,16 & & & & \\
\hline Workload & $-0,09$ & 0,06 & $-0,10$ & $-1,55$ & 0,12 & & & & \\
\hline Job security & 0,14 & 0,09 & 0,11 & 1,63 & 0,11 & & & & \\
\hline \multicolumn{4}{|l|}{ Dedication - Step 1} & & & $28,72 *$ & 0,55 & 0,30 & $0,30 *$ \\
\hline (Constant) & 33,96 & 1,74 & & 19,54 & 0,00 & & & & \\
\hline Organisational support & $-0,22$ & 0,03 & 0,54 & $-6,98$ & $0,00 *$ & & & & \\
\hline Resources & 0,02 & 0,08 & 0,02 & 0,21 & 0,83 & & & & \\
\hline Advancement opportunities & $-0,04$ & 0,07 & 0,04 & $-0,56$ & 0,58 & & & & \\
\hline \multicolumn{4}{|l|}{ Dedication - Step 2} & & & $20,48^{*}$ & 0,59 & 0,34 & $0,04 *$ \\
\hline (Constant) & 38,56 & 2,38 & & 16,23 & 0,00 & & & & \\
\hline Organisational support & $-0,21$ & 0,03 & 0,51 & $-6,61$ & $0,00 *$ & & & & \\
\hline Resources & 0,00 & 0,08 & 0,00 & 0,03 & 0,97 & & & & \\
\hline Advancement opportunities & $-0,05$ & 0,07 & 0,05 & $-0,75$ & 0,46 & & & & \\
\hline Workload & $-0,19$ & 0,06 & $-0,20$ & $-3,43$ & $0,00^{*}$ & & & & \\
\hline Job security & 0,07 & 0,09 & 0,05 & 0,82 & 0,42 & & & & \\
\hline
\end{tabular}

${ }^{*} p<0,01$ 
Table 7 shows that $30 \%$ of the variance in Dedication (as measured by the UWES) is predicted by job resources (as measured by the JDRS). However, only the regression coefficient of Organisational Support $(\beta=0,54 ; p<0,01)$ was statistically significant. Furthermore, $34 \%$ of the variance in Dedication (as measured by the UWES) is predicted by the factors of the JDRS. However, only the regression coefficients of Organisational Support $(\beta=0,51$; $p<0,01)$ and Workload $(\beta=-0,20 ; p<0,01)$ were statistically significant.

\section{Discussion}

This study set out to investigate the relationships between job demands, job resources, burnout, and work engagement. In support of the COBE model (Schaufeli \& Bakker, 2004), the Pearson correlation analysis confirmed that burnout (consisting of exhaustion and cynicism) was negatively related to engagement (consisting of vigour and dedication). Low levels of burnout were related to high levels of engagement (i.e. high levels of energy related to high levels of identification), confirming the findings of Schaufeli, Martinez, Pinto, Salanova and Bakker (2002).

Exhaustion was positively related to job demands because of workload (which encompassed physical, emotional and cognitive workload), and negatively related to job resources because of insufficient organisational support (which focused mainly on management support, communication, performance feedback, participative decision-making, work autonomy and role clarity). Maslach et al. (2001) found strong correlations between job demands (heavy workload and time pressure) and exhaustion. The findings of this study confirmed the theory underlying the JD-R model (Demerouti et al., 2001) that job demands are primarily related to exhaustion.

Cynicism correlated negatively with job resources because of lack of organisational support and advancement opportunities (which included growth, development and promotional opportunities). Barkhuizen (2005) reported similar findings. Both burnout dimensions were negatively related to organisational commitment, i.e. turnover intentions, and positively related to both physical and psychological ill health. Barkhuizen (2005) also reported exhaustion to be related to ill health. Research has linked burnout with various physical and psychological health problems (Lee \& Ashforth, 1990). Maslach (1998) and Wiese, Rothmann and Storm (2003) found a strong correlation between exhaustion and high job demands. Storm and Rothmann (2003b) confirmed the association between exhaustion and lack of job resources.

Regarding the positive outcomes of wellness, vigour and dedication were positively related to job resources because of organisational support and advancement opportunities. Coetzer and Rothmann (2004) found that job demands and a lack of job resources increased levels of burnout, while availability of resources increased levels of engagement. This study further confirmed the theory of the JD-R model (Demerouti et al., 2001) that lack of job resources are related primarily to disengagement.
The results of the multiple regression analyses also supported the underlying theory of the COBE model and confirmed that burnout is predicted by job demands (workload and job insecurity) and lack of job resources (insufficient organisational support and advancement opportunities), whereas engagement is predicted by availability of job resources (organisational support). In this study, exhaustion was predicted by job demands because of workload and job insecurity, as well as by lack of resources that included mainly collegial assistance, insufficient equipment and unfamiliarity with new technology. Cynicism was best predicted by lack of job resources (inadequate organisational support and lack of advancement opportunities). Maslach (1998) cited that cynicism was best predicted by job demands (work overload and social conflict).

Therefore this study confirmed the first hypothesis that burnout is predicted by job demands and a lack of job resources. It was clear from the results that the exhaustion component of burnout was predicted by overload (pace and amount of work and quantitative overload), job insecurity and a lack of resources (including equipment, staff and financial resources), while cynicism was predicted by a lack of organisational support. The second hypothesis, which stated that work engagement is predicted by job resources, is also accepted. It can be concluded, however, that organisational support (including managerial support, communication, role clarity and the extent of work autonomy) has a strong effect on both the vigour and dedication components of work engagement.

It can thus be said that job demands because of high workload and job insecurity together with lack of job resources because of insufficient organisational support and advancement opportunities contributed to a significant level of exhaustion in this study. Exhaustion (low energy) reduces engagement (identification). Existing theoretical relationships between burnout and engagement as well as burnout and ill health were confirmed in this study, and specifically the theory that burnout develops in response to excessive job demands and diminished job resources (Schaufeli \& Bakker, 2004).

The results should be interpreted in view of the current transformation process in the organisation and the history of the organisation. Eight months ago the organisation commenced with restructuring aimed at becoming a worldclass organisation and reducing costs. The new organisational design includes centres of excellence and shared business services that will result in job losses and possible demotions. The majority of affected employees are within the management ranks. Although the aims of the restructuring exercise were communicated eight months ago, communication on progress made has been limited and the appointment of employees into their new roles has been extremely slow. It is likely that the situation has increased the anxiety levels of the employees in the organisation, that it has contributed to the current levels of job insecurity experienced by the participants, as well as to a sense of reduced control, participation in decision-making and job autonomy. 
Simultaneously, other change initiatives such as continuous improvement, an enterprise resource system and a culture change initiative were implemented. The organisation expects its managers to embrace and champion the change initiatives. According to Maslach and Leiter (1997), major organisational transitions increase managers' workload in three ways: it becomes more intense and more complex and demands more time. It can thus be argued that the workload (physical, emotional and cognitive) of the managers has increased significantly over the past eight months. However, their job resources have not increased.

In conclusion, it can be argued that participants developed exhaustion in response to a significant increase in workload, high levels of job insecurity, and insufficient job resources. This resulted in psychological withdrawal (i.e. cynicism, reduced dedication and vigour) both from the work and the organisation. This is similar to findings cited by Maslach et al. (2001) in a meta-analysis of burnout and engagement research. The results confirmed the underlying theory of the COBE model. Work wellness (burnout and engagement) was predicted by both job demands (workload and job insecurity) and lack of job resources (lack of organisational support and advancement opportunities). Organisational commitment was predicted by work wellness (burnout and engagement).

The present study has certain limitations. The research was a cross-sectional survey design. As a result, no causal inferences could be drawn, even though advanced analytical procedures were employed. Another limitation is that the measurement of this model's variables was based solely on self-reports. Furthermore, the study population was very homogeneous. From a sample of 202 managers, 88,6\% were male, and $84,7 \%$ white. South Africa's multicultural society necessitates studying the constructs burnout, engagement and organisational commitment for managers from different cultural groups, and proving the construct equivalence and the absence of item bias for these groups. Future studies should include larger sample sizes.

\section{Recommendations}

Given the pervasive nature of burnout, organisations should adopt a preventative approach. According to Kompier and Kristensen (2001), interventions may, primarily be directed at the work situation or the coping capacity of employees. Work-oriented interventions aim at improving the fit between an individual and the workplace to the benefit of the individual and the organisational system. Employeeoriented interventions aim at teaching employees effective stress management skills, or skills to modify their appraisals of stressful situations as being less stressful. In the context of the organisation, effective human resource systems including career development and performance management - should be implemented as a matter of priority.

Secondly, interventions may be aimed at eliminating, reducing or altering stressors (primary interventions). Possible interventions include: changes in decision-making processes, work redesign, and provision of a more supportive climate (including constructive performance feedback). Thirdly, secondary-level interventions can be implemented to prevent employees who are already showing signs of stress from getting sick, and to increase their coping capacity. Examples of this strategy include cognitive restructuring, time management, conflict resolution techniques and coping strategies.

More research should be conducted on how to prevent burnout and enhance engagement. Research should also be conducted to evaluate the effectiveness of interventions.

\section{Acknowledgement}

This material is based upon work supported by the National Research Foundation under grant number 2053917.

\section{References}

Arbuckle, J.L. 1999. Amos 4.0. Chicago, IL: Smallwaters.

Barkhuizen, E.N. 2005. 'Work-related well-being of academic staff in a higher education institution'. Unpublished master's dissertation, North-West University, Potchefstroom.

Blix, A.G., Cruise, R.J., Mitchell, B.M. \& Blix, G.G. 1994. 'Occupational stress among university teachers', Educational Research, 36: 157-169.

Burke, R.J. \& Richardsen, A.M. 1993. 'Psychological burnout in organizations'. In Golembiewski, R.T. (Ed.). Handbook of organizational behaviour. New York: Dekker, p.p. 263-298.

Clark, L.A. \& Watson, D. 1995. 'Constructing validity: Basic issues in objective scale development', Psychological Assessment, 7: 309-319.

Coetzer, W.J. \& Rothmann, S. 2004. 'A model of work wellness of employees in an insurance company'. Poster presented at $28^{\text {th }}$ International Congress of Psychology, Beijing, China.

Cohen, J. 1988. Statistical power analysis for the behavioural sciences. Revised edition. Orlando, FL: Academic Press.

Cordes, C.L. \& Dougherty, T.W. 1993. 'A review and integration of research on job burnout', Academy of Management Review, 18: 621-656.

Csikszentmihalyi, M. 1990. Flow: The psychology of optimal experience. New York: Harper.

Demerouti, E., Bakker, A.B., Nachreiner, F. \& Schaufeli, W.B. 2001. 'The job demands-resources model of burnout', Journal of Applied Psychology, 86: 499-512.

DuBrin, A.J. 1990. Effective business psychology $\left(3^{\text {rd }}\right.$ Edition). Englewood Cliffs, NJ: Prentice-Hall.

Gastrow, P. 2001. 'Theft from South African mines and refineries. The illicit market for gold and platinum', Monograph, $54 . \quad$ [online] URL: 
http:/www.iss.co.za/Pubs/Monographs/No54/Chap1 html. Accessed 21 October 2004.

Hobfoll, S.E. \& Freedy, J. 1993. 'Conservations of resources: A general stress theory applied to burnout'. In Schaufeli, W.B., Maslach, C. \& Marek, T. (Eds.). Professional burnout: Recent developments in theory and research. Washington, DC: Taylor \& Francis, p.p. 115-129.

Ivancevich, J.M. \& Matteson, M.T. 1999. Organizational behaviour and management ( $5^{\text {th }}$ Edition). Singapore: Irwin McGraw-Hill.

Jackson, L.T.B. \& Rothmann, S. 2005. 'An adapted model of burnout for educators in South Africa', South African Journal of Education, 25: 100-108.

Jackson, L.T.B., Rothmann, S. \& Van de Vijver, F.J.R. 2006. 'A model of work-related well-being for educators in South Africa in the North West Province', Stress and Health 22: $263-274$.

Jackson, W.K. \& Simpson, R.D. 2001. 'The implementation of a faculty development model emphasising personal as well as professional renewal', Education, 106: 434-441.

Kompier, A.J. \& Kristensen, T.S. 2001. 'Organisational work stress interventions in a theoretical, methodological and practical context'. In Dunham, J. (Ed.). Stress in the workplace: Past, present and future. London: Whurr Publishers, pp. 19-33.

Lee, R.T. \& Ashforth, B.E. 1990. 'On the meaning of Maslach's three dimensions of burnout', Journal of Applied Psychology, 6: 743-747.

Lee, R.T. \& Ashforth, B.E. 1996. 'A meta-analytic examination of the correlates of three dimensions of burnout', Journal of Applied Psychology, 81: 123-133.

Leiter, M.P. 1993. 'Burnout as a developmental process: Consideration of models'. In Schaufeli, W.B. Maslach, C. \& Marek, T. (Eds.) Professional burnout: Recent developments in theory and research. Washington, DC: Taylor \& Francis.

Leiter, M.P. \& Harvie, P. 1998. 'Conditions of staff acceptance of organisational change: Burnout as mediating construct', Anxiety, Stress and Coping, 11: 1-15.

Maher, E.L. 1983. 'Burnout and commitment: A theoretical alternative', Personal and Guidance Journal, 61: 390-393.

Maslach, C. 1998. 'A multi-dimensional view of burnout'. In Cooper, C.L. (Ed.). Theories of organizational stress. Oxford, UK: Oxford University Press, pp. 68-85.

Maslach, C., Jackson, S.E. \& Leiter, M.P. 1996. Maslach Burnout Inventory: Manual ( $3^{\text {rd }}$ Edition). Palo Alto, CA: Consulting Psychologists Press.

Maslach, C. \& Leiter, M.P. 1997. The truth about burnout: How organisations cause personal stress and what to do about it. San Francisco, CA: Jossey-Bass.
Maslach, C., Schaufeli, W.B. \& Leiter, M.P. 2001. 'Job burnout', Annual Review of Psychology, 52: 397-422.

Minervini, R., Meyer, M. \& Rourke, L. 2003. Human capital management: A handbook for SA managers. Johannesburg: WriteStuff Publishing.

Nelson, D.L. \& Simmons, B.L. 2003. 'Health psychology and work stress: A more positive approach'. In Quick, J.C. \& Tetrick, L.E. (Eds.). Handbook of occupational health psychology. Washington, DC: American Psychological Association, pp. 97-119.

Nunnally, J.C. \& Bernstein, I.H. 1994. Psychometric theory ( $3^{\text {rd }}$ Edition). New York: McGraw-Hill.

Rothmann, S. 2002. 'Burnout and engagement: A fortigenic perspective'. Inaugural lecture presented at the North-West University, Potchefstroom.

SPSS Inc. 2003. SPSS 12.0 for Windows. Chicago, IL: Author.

Schaufeli, W.B. 2003. 'Past performance and future perspectives of burnout research', South African Journal of Industrial Psychology, 29: 1-15.

Schaufeli, W.B. \& Bakker, A.B. 2001. 'Werk en welbevinden: Naar een positive benadering in de arbeids- en gezondheidspsychologie' \{Work and well-being: Towards a positive approach to occupational and health psychology Gedrag en Organizatie, 14: 229-253.

Schaufeli, W.B. \& Bakker, A.B. 2004. 'Job demands, job resources, and their relationship with burnout and engagement: A multi-sample study', Journal of Organizational Behavior, 25: 293-315.

Schaufeli, W.B. \& Buunk, B.P. 1996. 'Professional burnout'. In Schabracq, M.J., Winnubst, J.A.M. \& Cooper, C.L. (Eds.). Handbook of work and health psychology. Chichester: Wiley, p.p.311-346.

Schaufeli, W.B. \& Enzmann, D. 1998. The burnout companion to study and practice: A critical analysis. London: Taylor \& Francis.

Schaufeli, W.B., Martinez, I., Pinto, A.M., Salanova, M. \& Bakker, A.B. 2002. 'Burnout and engagement in university students: A cross-national study', Journal of Cross-Cultural Psychology, 33: 464-481.

Schaufeli, W.B., Salanova, M., González-Romá, V. \& Bakker, A.B. 2002. 'The measurement of engagement and burnout: A confirmative analytic approach', Journal of Happiness Studies, 3: 71-92.

Schaufeli, W.B., Van Dierendonck, D. \& Van Gorp, K. 1996. 'Burnout and reciprocity: Towards a dual-level social exchange model', Work and Stress, 10: 225-237. 
Seiler, R.E. \& Pearson, D.A. 1984-5. 'Dysfunctional stress among university faculty', Educational Research Quarterly, 9: $15-26$.

Seligman, M.E.P. \& Csikszentmihalyi, M. 2000. 'Positive psychology: An introduction,' American Psychologist, 55: 5-14.

Shirom, A. 1989. 'Burnout in work organizations'. In Cooper, C.L. \& Robertson, I. (Eds.). International review of industrial and organizational psychology. Chichester: Wiley, p.p. 25-48.

Storm, K. \& Rothmann, S. 2003a. 'A psychometric analysis of the Maslach Burnout Inventory - General Survey in the South African Police Service', South African Journal of Psychology, 33: 219-226.

Storm, K. \& Rothmann, S. 2003b. 'A psychometric analysis of the Utrecht Work Engagement Scale in the South African Police Service', South African Journal of Industrial Psychology, 29: 62-70.

Tabachnick, B.G. \& Fidell, L.S. 2001. Using multivariate statistics $\left(4^{\text {th }}\right.$ Edition). Boston, MA: Allyn \& Bacon.

Taris, T.W., Schreurs, P.J.G. \& Schaufeli, W.B. 1999. 'Construct validity of the Maslach Burnout Inventory General Survey: A two-sample examination of its factor structure and correlates,' Work and Stress, 13: 223-237.

Watts, W.D., Cox, L., Wright, L.S., Garrison, J., Herkimer, A. \& Howze, H.H. 1999. 'Correlates of drinking and drug use by higher education faculty and staff: Implications for prevention,' Journal of Drug Education, 21(1): 43-64.

Wiese, L., Rothmann, S. \& Storm, K. 2003. 'Coping, stress and burnout in the South African Police Service in KwaZulu-Natal', South African Journal of Industrial Psychology, 29(3): 71-80.

World Competitiveness Yearbook. [online]

URL:http://www01.imd.ch/wcy/. Accessed 19 October 2004. 